\section{The mischief maker}

\section{J.O. Marsh}

\section{The Demon in the Aether: The Story of James Clerk Maxwell. \\ By Martin Goldman. \\ Paul Harris, 40 York Place, Edinburgh: 1983. Pp.224. fl8.}

JAMES Clerk Maxwell was more an imp in the underdrawings than a demon in the aether. True, his mischievous activity so undermined classical physics as to bring it to ruins, but that was not until 30 years after his death. Demon or imp, Maxwell remains an insubstantial figure behind the pages of Goldman's biography.

The facts of Maxwell's life have been established by other scholars. His father devoted most of his married life to developing and improving the family estate, Glenlair in Galloway. James, the only surviving child of the marriage, was educated by his mother until, when he was eight, she died. His father continued the schooling initially by having James assist him with his improvement schemes and later by employing a tutor. The tutor was a disaster and, at the age of ten, James was sent to live with his aunts so that he could attend the Edinburgh Academy. There he made two lifelong friends, Lewis Campbell and Peter Guthrie Tait, and gained the nickname "Dafty".

After six years of learning classics at the Academy, Maxwell entered Edinburgh University. He remained there for three years (perhaps to stay near his father), studying mathematics under Phillip Kelland, philosophy under William Hamilton (not the Irish mathematician) and natural philosophy under James Forbes. Then on to Cambridge and the "Public Service" examination, the maths tripos. He was second in the tripos to Routh but equal first with him in the unofficial physics examination, the Smith's prize.

After Cambridge, Maxwell's career was spectacular only by his early death. He spent two years as Scholar and then Fellow of Trinity College, four years as Professor of Natural Philosophy at Marischal College, Aberdeen, five years at King's College, London, and then six years retirement at Glenlair (completing his father's schemes on a considerably reduced scale). He failed in an application to become Principal of St Andrews in 1868 and was third choice to direct the new Cavendish Laboratory at Cambridge. However, the two preferred candidates (Kelvin and Helmholtz) declined and Maxwell was appointed Cavendish Professor of Experimental Physics in 1871 . He died of stomach cancer eight years later.

Maxwell's official biography was written by his Academy friend, Lewis Campbell, and his Cavendish Laboratory assistant, William Garnett, and first published in 1882. This six-hundred page classic of Vic- torian sentimental hagiography is the main source for the ten biographical chapters of Goldman's book. By cutting extensive quotations to "juicy" paragraphs, by adding a bit of gossip about Maxwell's wife and by suggesting that Maxwell's religious belief was conventional "religiosity", Goldman presents Campbell and Garnett's Maxwell suitably repackaged for our modern Victorian age.

In the 1882 biography, William Garnett described Maxwell's scientific contributions under seven headings: experiments on colour vision and other contributions to optics; investigations respecting elastic solids; pure geometry; mechanics; Saturn's Rings; Faraday's lines of force and Maxwell's theory of the electromagnetic field; and molecular physics. Garnett stated that his contemporaries judged the latter two as most important and in this posterity has shown them to be correct, though not in the way they might have expected. Maxwell's electromagnetic theory led directly (not via the Michelson-Morley experiment) to Einstein's theory of special relativity, and his molecular physics (dynamical theory of gases) led to statistical physics and quantum mechanics.

Goldman devotes four chapters to Maxwell's scientific work: one each to the dynamical theory of gases and electromagnetic theory, one to the revolutionary consequences of these theories and one to the rest of Maxwell's scientific work. Apart from the latter, which is little more than the catalogue above, each of these accounts is

\section{Public knowledge}

\section{Jonathan C. Howard}

\section{Aristotle to Zoos: A Philosophical}

Dictionary of Biology.

By P.B. and J.S. Medawar.

\section{Weidenfeld \& Nicolson/Harvard}

University Press: 1984. Pp.305.

£15, \$18.50.

IT IS necessary only to open the Sunday papers to discover that the educated man in the street has recently adopted biology as a topic for generalized opinion and discussion. It is hardly surprising that biology should be the first science whose basic concepts enjoy universal currency. Biology alone among the sciences has been taught to all schoolchildren in the Western world for over a generation. The primitive traditions underlying the organization of schools have been allowed to deny most girls a proper education in mathematics and the physical sciences. As the girls and the physical sciences have lost from this mad policy, so biology has gained. Minds cultivated in biology are now as common among women as among men. In the biological sciences it is therefore no surprise, only a pleasure, to find a husband and wife sharing the writing of a book, and it is seriously flawed. So, in the chapter on the dynamical theory, Goldman claims that the analytical methods of Fourier are "an abstract mathematical technique, far from the geometrical methods 'normally' associated with Maxwell"' (p.110). This is nonsense. Part of Maxwell's genius lay in his ability to switch from geometrical to analytical methods and back, and this he did frequently and to great effect.

In the chapter on electromagnetism, Goldman states "It seems quite remarkable that Maxwell's book, which even today is a model of precision and clarity, should have appeared murky and impenetrable to his contemporaries"' (p.159). Three pages later Goldman himself identifies the great problem with Maxwell's theory: "Underlying the whole theory was the basic ambiguity of the nature of charge"' (p.163).

Goldman is either unaware of, or has ignored, the work published over the past ten years of at least a dozen scholars. Attention to that literature might have helped him avoid many errors, but I doubt if anything would have deflected him from the triteness of his conclusions:

As a boy he electroplated beetles and played marbles ('bools') as a man he unified electromagnetism and founded statistical mechanics. There is a wholeness in the circularity and immutability of his interests [p. 195].

J.O. Marsh is a Lecturer in the Department of History of Science and Technology, UMIST, Manchester.

especially apt that the book should be a work intended to enlighten still further the biologically literate general public.

Aristotle to Zoos is an odd book. Ostensibly based on Voltaire's Philosophical Dictionary, the Medawars have used the format as an excuse to write as much or as little as they wanted on whatever biological topics they fancied. This is, of course, a recipe for selfindulgence, and the book is not entirely free from this vice. Turning to the entry on Aristotle, for example, the startled reader discovers that for some reason the Medawars have it in for the old boy in a big way, quirkily preferring Coleridge as a superior alternative, and muttering about monkeys on a typewriter. I suspect that $\mathrm{Sir}$ Peter Medawar may have allowed his distaste for authors who write too much to get the better of his critical judgement. I remember a masterly Herbert Spencer Lecture given by Medawar in Oxford some years ago. Medawar had borrowed Spencer's gigantic System of Philosophy from the Royal Society library and transported it to the lecture theatre in Oxford in order to illustrate his gleeful pronouncement that he himself had been obliged to cut the pages. His disparaging view of Spencer was shared by the Dean of Westminster, who noted in 1904, while denying a request to bury Spencer in the Abbey, 